\title{
Exploration Ethnomathematics of the Malind Tribe for Building Character in Elementary Schools
}

\author{
Fredy', Yonarlianto Tembang1, Gregorius Sebo Bito², Octarina Hidayatus Sholikhah ${ }^{3}$ \\ 1 Univesritas Musamus Merauke, Indonesia \\ 2 Universitas Flores, Indonesia \\ 3 Universitas PGRI Madiun, Indonesia
}

Corresponding Author: Fredy, @ fredy_pgsd@unmus.ac.id

\begin{tabular}{|c|c|}
\hline \multirow{3}{*}{$\begin{array}{l}\text { ARTICLE INFO } \\
\text { Article history: } \\
\text { Received } \\
\text { June 23, } 2020 \\
\text { Revised } \\
\text { June 29, } 2020 \\
\text { Accepted } \\
\text { July 18, } 2020\end{array}$} & ABSTRACT \\
\hline & $\begin{array}{l}\text { This article aimed to explore ethnomathematics in the Malind tribe to } \\
\text { strengthen the character values of elementary school students. The } \\
\text { method used descriptive survey method with data collection techniques } \\
\text { such as observation, interviews, and literature review. The researchers } \\
\text { act as a human instrument. The qualitative data were obtained and then } \\
\text { analyzed by paying attention to ethnomathematics material or theme. } \\
\text { The results showed: firstly, ethnomathematics in the culture of the } \\
\text { Malind tribe was found in activities of daily life such as the manufacture } \\
\text { of farming tools, hunting, fishing, musical instruments, noken, ornaments } \\
\text { and paintings, traditional ceremonies, life behaviors, and traditional } \\
\text { games. Second, the attitude of responsibility, like to work hard, practice } \\
\text { religious values, develop creativity, friendship, responsibility, the spirit } \\
\text { of cooperation and kinship and tolerance is an integrated national } \\
\text { character in the cultural values of the Malind tribe. Ethnomathematics } \\
\text { can be integrated into learning mathematics in elementary schools }\end{array}$ \\
\hline & Keywords: Ethnomathematics, Malind Tribe, Education Character \\
\hline How to cite & $\begin{array}{l}\text { Fredy. F., Tembang, Y., Bito. G., \& Sholikhah, S. (2020). Exploration } \\
\text { Ethnomathematics of the Malind Tribe for Building Character in Elementary } \\
\text { Schools. IJoASER (International Journal on Advanced Science, Education, and } \\
\text { Religion), 3(2). 9-20. https://doi.org/10.33648/ijoaser.v3i2.58 }\end{array}$ \\
\hline $\begin{array}{l}\text { Journal Homepage } \\
\text { Published by }\end{array}$ & $\begin{array}{l}\text { https://ojs.staialfurqan.ac.id/IJoASER/ } \\
\text { STAI Al-Furqan Makassar }\end{array}$ \\
\hline
\end{tabular}

\section{INTRODUCTION}

Success in building human character reflects the success of building the nation's character. Edmonson et al. (2009) reported that the causes of the waning organization of character education influenced by individualism, pluralism, and secularism. Moral decadence that occurs in society in Indonesia makes human interaction and the environment no longer sourced from noble values and religion. Degradation moral that continues until now makes it increasingly difficult to prevent and overcome them (Adam et al., 2019); Ampuni et al., 2019). The deviant nature of children at school age such as drunkenness, abuse, free sex, or drug abuse is increasingly widespread and difficult to handle (McAlpin, 2016; Muthohar, 2016). Examples of cases in the Merauke district are the incidence of aibon children whose numbers are increasing and their subscriptions are not optimal.

One way to strengthen character values is by integrating ethnomathematics in mathematics learning in elementary schools. Strengthening character since elementary school is expected to be a strong moral foundation to face higher education 
(Yustinaningrum et al., 2018; Agustin et al., 2018). Ethnomathematics learning by integrating the value of local wisdom, helps students understand contextual mathematics material (Risdiyanti \& Prahmana, 2017; Herawaty et al., 2019). It also strengthens the noble values of the culture as the values of national character (Nugroho, 2018). D'Ambrosio in 1977 introduced the idea of linking mathematics in culture to what is known as ethnomathematics. Literally, "ethno" is defined as a sociocultural product, while "mathema" is defined as human activity in coding, measuring, classifying, drawing conclusions, and designing models. The word "tics" can be interpreted as a method (Wahyuni et al., 2013). Ethnomathematics can be interpreted as a technique to explain and understand mathematics derived from certain cultural values.

Some research results showed that the relationship between mathematics and culture and illustrate the success of ethnomathematics in strengthening the value of character in students. Kurniawan \& Hidayati (2020) research in Borobudur architecture was built utilizing mathematical concepts such as numbering, geometry, even the concepts of logic and space configuration. In the Marawis musical instrument style, geometric shapes are formed in a circle and mathematical concepts in the form of reflection, translation, folding symmetry, rotary symmetry, acute angle, and obtuse angle (Afriyanty \& Izzati, 2019). Likewise, Mutijah (2018) research shows that ethnomathematics on sliced set material can be integrated with Islamic values and local wisdom values. The difference between this and previous research is that it explores ethnomathematics in the culture of the Malind tribe as local identity.

This article aimed to explore ethnomathematics in Malind tribal culture that can be used for character education in elementary schools. This is because ethnomathematics provides an opportunity to link mathematical material with the local wisdom of a region. Through this exploration, it is expected that the mathematics material contained in the Malind culture can be applied in mathematics learning in elementary schools so that it can provide contextual student learning experiences and strengthen the values of character based on local wisdom.

\section{METHODS}

This study used qualitative research with an ethnographic approach (Creswell, 2014; O'Dwyer \& Bernauer, 2013). The descriptive survey method applied aims to describe the results of ethnomathematics exploration of the Malind tribe in order to strengthen character values in elementary schools in Merauke district. Observation and participatory observation techniques were chosen in this study. Hence, the researchers can observe directly on the observed object. Sampling technique used a cluster random sampling technique. This technique was chosen because not all villagers consisted of Malind tribal people. In addition, such a large location allows the determination of samples based on the number of Maling people who inhabit a village. The researcher acts as an instrument (human instrument). The consequence is the position of the researcher who cannot be represented by the others. The researcher himself compiles the plan, selects the correspondence as a source of data, collects and collects data, makes interpretation of the data, and draws conclusions on his findings. The interview guide is used to direct the researcher to the desired goal.

The data obtained is qualitative data that has been compiled to look for material or theme ethnomathematics in the Malind tribal community. Data were analyzed based on cultural themes to find conceptual knowledge of the Malind culture. Next look for a universal relationship between culture and mathematics 
(ethnomathematics), the relationship between ethnomathematics and character values based on Malind culture. The researcher also explored further if there are sub-sections of the cultural theme and then is presented in a table that illustrates the connectedness of the theme.

\section{RESULT AND DISCUSSION}

All human activities in daily life are inseparable from the mathematical activities that follow. Similarly, the activities of the Malind tribe community contain many elements or mathematical material in it. Activities and culture of the Malind tribe can be found in dances, musical instruments, ornaments or carvings, farming tools, hunting tools, traditional houses and children's games. The focus of research on these activities and cultures allows exploration to discover the mathematical material contained therein.

Malind tribe or Malind Anim is an indigenous tribe who inhabit the southern part of Papua, especially in Merauke district. The original belief of the Marind tribe is still oriented to the power of the spirit called dema. The power of this dema is believed to originate from supernatural powers that are in nature or the spirits of ancestors who have died. Christian missionaries entered the southern region of Papua in 1910, since then and until now the majority of the Malind people are Christians (Amri, 2017). There are seven clans in the Malind tribal community, including gebze (coconut), ndiken (bird), basik (pig), kaize (cassowary), mahuze (dog), samkakai (stock) and balaigeze (crocodile) (Dinas Kebudayaan dan Pariwisata, 2015). Each village has a traditional leader who is highly respected and respected. Every order or prohibition of the traditional leader must be obeyed and carried out.

The data collected showed some activity and cultural products Malind tribal communities containing material/mathematical concepts and values of the characters therein. The mathematical concepts and character values contained therein are prepared by following the scientific method that has been designed previously. The findings that have been collected are presented in Table 1.

Table 1. Mathematical Concepts that Contained Malind Tribal Culture

\begin{tabular}{|c|c|c|c|c|}
\hline No & $\begin{array}{l}\text { Cultural } \\
\text { Products }\end{array}$ & Information & $\begin{array}{c}\text { Mathematical } \\
\text { Concepts }\end{array}$ & Character Value \\
\hline 1 & $\begin{array}{l}\text { hoe and } \\
\text { wooden } \\
\text { shovel }\end{array}$ & $\begin{array}{l}\text { used to dig or loose fields. } \\
\text { hoe or translucent made } \\
\text { from mangrove wood or } \\
\text { other hard wood that is } \\
\text { pulled up to its roots }\end{array}$ & $\begin{array}{l}\text { measurements } \\
\text { of length, } \\
\text { angles, } \\
\text { geometry }\end{array}$ & $\begin{array}{l}\text { responsible, hard } \\
\text { work }\end{array}$ \\
\hline 2 & $\begin{array}{l}\text { seser dan } \\
\text { bow }\end{array}$ & $\begin{array}{l}\text { used to catch fish such as } \\
\text { mujair, gabus and other } \\
\text { freshwater fish. Seser } \\
\text { made of woven bamboo } \\
\text { while the bow made of } \\
\text { wood that made the } \\
\text { pointed ends }\end{array}$ & $\begin{array}{l}\text { concept of } \\
\text { numbers, } \\
\text { angles }\end{array}$ & $\begin{array}{l}\text { responsible, hard } \\
\text { work }\end{array}$ \\
\hline 3 & $\begin{array}{l}\text { arrows } \\
\text { and iwan }\end{array}$ & $\begin{array}{l}\text { used for hunting animals } \\
\text { such as pigs, deer, } \\
\text { kangaroos (saham), } \\
\text { cassowaries and other }\end{array}$ & $\begin{array}{l}\text { measurements } \\
\text { of length, } \\
\text { circle }\end{array}$ & $\begin{array}{l}\text { Responsible, } \\
\text { hard work }\end{array}$ \\
\hline
\end{tabular}




\begin{tabular}{|c|c|c|c|c|}
\hline No & $\begin{array}{l}\text { Cultural } \\
\text { Products }\end{array}$ & Information & $\begin{array}{c}\text { Mathematical } \\
\text { Concepts }\end{array}$ & Character Value \\
\hline 4 & $\begin{array}{l}\text { Tifa } \\
\text { (kandara) }\end{array}$ & $\begin{array}{l}\text { wild animals } \\
\text { musical instruments that } \\
\text { are played in a drum like } \\
\text { a drum. Kandara is used as } \\
\text { a dance accompaniment } \\
\text { at traditional ceremonies, } \\
\text { deaths, the release of sasi } \\
(\text { tep) and inisiasi }\end{array}$ & $\begin{array}{l}\text { Angular and } \\
\text { plane, solid } \\
\text { (geometry) } \\
\text { concept }\end{array}$ & $\begin{array}{l}\text { religious, } \\
\text { creative }\end{array}$ \\
\hline 5 & $\begin{array}{l}\text { ornaments } \\
\text { or paintings } \\
\text { of kandara } \\
\text { and faces }\end{array}$ & $\begin{array}{l}\text { art as a symbol of } \\
\text { worldview. } \\
\text { ornamentation is found in } \\
\text { paintings and coloring of } \\
\text { tifa or fractal geometry } \\
\text { faces developing } \\
\text { creativity }\end{array}$ & $\begin{array}{l}\text { fractal } \\
\text { geometry }\end{array}$ & creative \\
\hline 6 & pinang sirih & $\begin{array}{l}\text { chewing pinang sirih } \\
\text { known as alas tikar. Pinang } \\
\text { sirih must be provided in } \\
\text { traditional community } \\
\text { events }\end{array}$ & $\begin{array}{l}\text { integer } \\
\text { operation }\end{array}$ & $\begin{array}{l}\text { integer operation } \\
\text { friendship, hard } \\
\text { work, social } \\
\text { attitude }\end{array}$ \\
\hline 7 & bakar batu & $\begin{array}{l}\text { Stones are heated and the } \\
\text { steam is used for cooking } \\
\text { crops or hunted }\end{array}$ & $\begin{array}{l}\text { integer } \\
\text { operation }\end{array}$ & $\begin{array}{l}\text { responsible, } \\
\text { hard work, } \\
\text { family }\end{array}$ \\
\hline 8 & noken & $\begin{array}{l}\text { a device used for mothers } \\
\text { to raise crops, groceries, } \\
\text { firewood and baby } \\
\text { carriers }\end{array}$ & geometry & $\begin{array}{l}\text { hard work, } \\
\text { creative }\end{array}$ \\
\hline 9 & $\begin{array}{l}\text { traditional } \\
\text { hous }\end{array}$ & $\begin{array}{l}\text { function as a family } \\
\text { residence (oram aha). there } \\
\text { is also a single house } \\
\text { (gotad) or home for } \\
\text { women who will give } \\
\text { birth }\end{array}$ & $\begin{array}{l}\text { Angular and } \\
\text { plane, solid } \\
\text { (geometry) } \\
\text { concept }\end{array}$ & $\begin{array}{l}\text { Responsible, hard } \\
\text { work, } \\
\text { independent, } \\
\text { tolerance }\end{array}$ \\
\hline 10 & Archery & $\begin{array}{l}\text { Local game Malind tribe. } \\
\text { Archery is played as a } \\
\text { team by children }\end{array}$ & $\begin{array}{l}\text { the concept } \\
\text { of distance }\end{array}$ & $\begin{array}{l}\text { responsible, } \\
\text { friendship, } \\
\text { tolerance }\end{array}$ \\
\hline
\end{tabular}

To ensure the validity of the data obtained on the activities and culture of the Malind tribe, it is then compared with the results of the literature review and interviews with Malind cultural figures from the education and culture department of the Merauke district. Informant sources came from the Malind tribe in Wasur, Buti, Lampu Satu and Payum villages. 


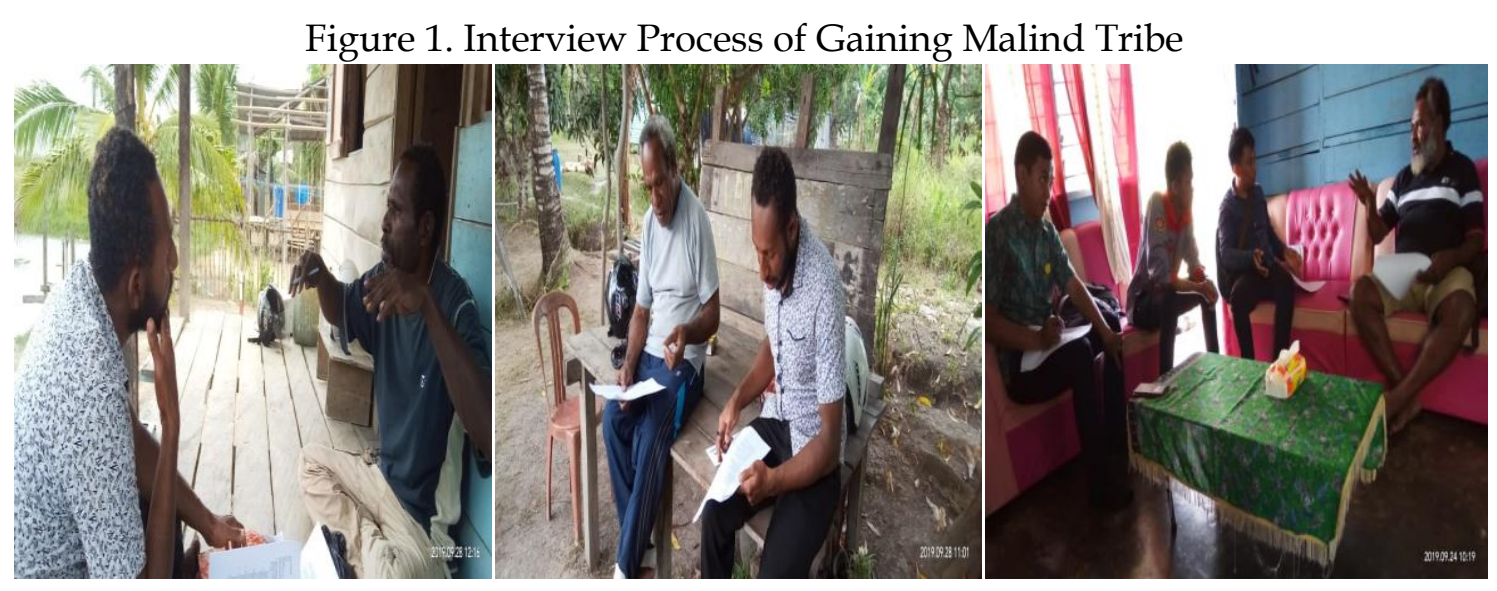

Malind tribal settlements are more scattered on the outskirts of the district of Merauke such as Samkai or Kamadehoga. This is due to their tendency to live in coastal areas of the sea or rivers, so that their livelihoods are not far from fishing or farming activities in the coastal areas. They still use simple settlement patterns and live in groups (Amri, 2017). The results of interviews with informants stated that the Malind tribal farming system is still traditional, only by loosening the soil using simple tools. Formerly hoes and shovels to dig or loosen the soil made of wood or hard wood roots.

$\mathrm{P} \quad$ : How do you farm Malind?

I1 : How to farm Malind tribe by making a wambad or land that is given up for gardening. The tool used is using flattened wood that resembles a shovel that we call itto. There are also mangroves that are uprooted. The wood is made until the remaining two roots are made into earth diggers. Getana wood measuring one to two meters for a ground shovel. Getana wood is cut in the lower part of the stem, after that it is scraped until it is shaped with a scope. Getana wood is good for spades because it is strong.

Other informants mentioned that tools for digging the ground could also be made of wood with sharpened edges.

$\mathrm{P} \quad$ : What tools are used for digging or digging in the ground?

I2 : open iron wood as a hoe with pointed edges that functions to dig the soil. How to make it using roomy iron wood, iron wood is cut and scraped to resemble a pointed shape.

These agricultural tools contain mathematical concepts in them, including the concept of measurement. This can be seen from the size of hoe made between one to two meters, adjusted to the person who uses it. Hoe eyes made from mangrove roots have a size of 10-25 cm. Likewise with the concept of the angle and the concept of the cone appear from the shape of the hoe with a cone tip, between the stem and the hoe's eye forming a sharp angle or elbows. This is so as to facilitate and have the power to dig or breathe soil.

I1 : Mangroves are removed by the roots, mangrove stems are selected and the remaining two roots must be bent right or slightly entered into. If the roots are straight or bent out it is not good, not strong enough to dig up the soil.

Besides farming, the activity of the Malind tribe is fishing. Before there were fishing gears such as fishing rods and nets made of nylon, the inland Malind tribe used seser which is woven bamboo to catch fish. There are also bows or spears made of bamboo. The fish caught are freshwater fish such as tilapia, fish cork (gastor), catfish and other 
freshwater fish. The catch of freshwater fish in Merauke is large because the nature is still maintained.

I1 : first before there is a fishing tool so if we look for fish using seser made of woven bamboo and can also use a bow or spear.

Unlike the Malind tribe who live on the coast, they used to use coconut pelepa for string strings and woven coconut belts to make nets and the techniques to use it to form the letter " $U$ " in water so that many catches.

I2 : using a special wood that is the coconut pelepa which is taken in the middle to make a ray or a long-range nelon rope and the bait uses worms, there is also a net made of coconut coir, coconut coir is pulled out one by one to be woven together so as to get a rope, the rope is woven to make a net and the net to use it must be netted in the form of the letter " $U$ " so that it can get a lot of results.

The number of fish caught shows the number concept. Of course, the amount will be different if you use fishing gear and nets. Fishing techniques produce more catches than fishing using fishing rods. It is not surprising that the freshwater fish population in Merauke is very large and large because fish caught using fishing and fishing techniques. This can also protect freshwater ecosystems in Merauke. The concept of angles can be seen from fishing techniques. If fishing is seated, the angle formed between the hook and the fishing line forms a sharp angle, while by standing, the angle formed between the hook and the fishing line forms a blunt angle.

Hunting activities are activities that still survive today. Arrows are used to hunt animals such as pigs, deer, kangaroos (saham), cassowaries and other wild animals.

I1 : Use a bow made of bamboo. How to make it by using young bamboo one to two meters in size, scraped using snails or pig fangs, while feathers or tat one meter in size and spearhead are sangi-sangi made of nibung hearts.

Bow usually black. This coloring uses natural ingredients, namely grated coconut. The bow is wrapped in grated coconut and allowed to stand for a month until it turns black. There is also a snare tool called iwan which is a snare using a rattan rope and is assembled to resemble a paddle boat.

The concept of measurement in making arrows is known as khawanuk (measuring) with units of bamboo segments (buku). The length of the bow must exceed that of the person using it. The length of the bow for adults is 10-12 books while for children the length is up to six books (Supriyadi \& Nurvitasari, 2019). Unlike the case found by Santos (2019) in agricultural activities in rural Sergipe, Brazil found the concept of measurement in units of length using an adult human body. In archery activities, if the archery is at close range then the arrow is pulled up to the front of the chest but if the target is far away then the arrow is pulled up past the chest. Iwan or rattan meshes utilize the concept of a circle. The size of the circle of meshes is adjusted to the target's head.

Malind culture is very closely related to tifa music or commonly called kandara. This instrument is played by beating like a drum. Tifa is used as a dance accompaniment in traditional rituals, death, the release of sasi (tep) and inisiasi. The resulting sound (melody) will feel really sacred and become the main priority in every activity they hold. 
I1 : Tifa is made of special wood that is blackboard tree (kayu susu). The reason for using the blackboard tree is because the milk tree is a light and nice tree

The concept of geometry can be seen from the shape of the cylinder which resemble tubes with empty space in them. Similarly, the concept of the circle appears on the head of a circle. Tifa consists of three parts. The upper part is called the head of the tifa, the base is called the tail of the tifa and the center of the tifa is leaner and has a handle on the side (Fredy et al., 2020). The upper part is a part that is beaten with a surface made of kangaroo skin (saham), monitor lizards and snakes (patola). The top circle must be smaller than the bottom circle. If the head circle is $45 \mathrm{~cm}$, then the tail circle is $50 \mathrm{~cm}$, while the length of the drums is adjusted to the size of the person wearing them, ...... the size of the tifa is the chin boundary.

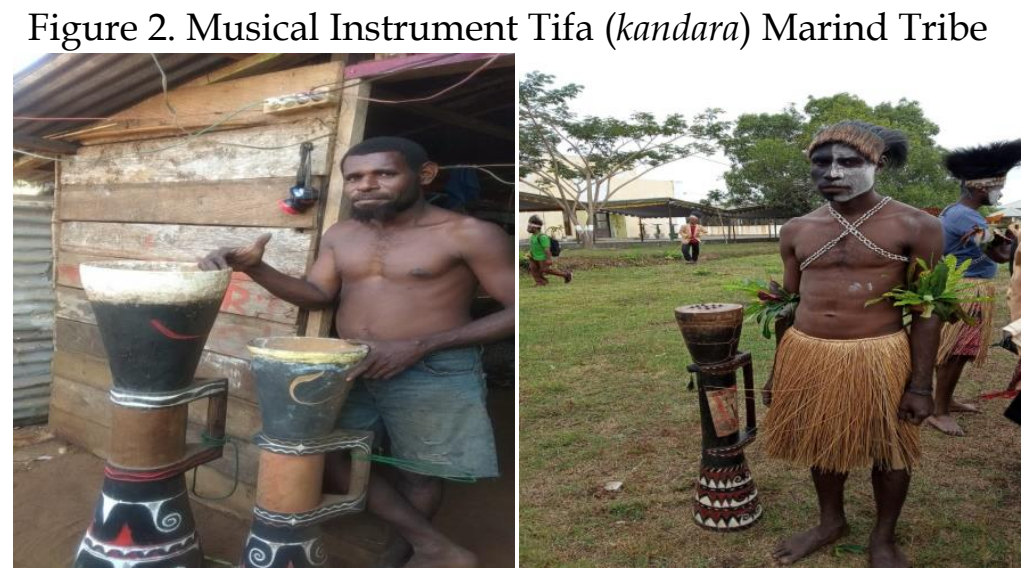

Malind cultural paintings can be seen from tifa paintings or face paintings. The paintings on the drapes form a circle around the drums, while the paintings on the faces of dancers in traditional dances contain the concept of fractal geometry. There are three color elements in tifa and face paintings, namely white, red and black. This contains the meaning and character of the Malind tribe. The black color is made of wood charcoal, black mud and bark. Burned then stirred with water or animal blood. The red color is made of red clay, red stone $(a h w a)$, pounded with a mixture of water and soaked. The white color is made of snails/shells, dried and then soaked with water (Ndiken, 2013). One of the life styles of the people of Papua in general is betel nut (pinang sirih). Chewing pinang sirih is practiced by all groups in society. Betel eating activities are usually done in groups can strengthen family relationships and foster motivation or enthusiasm for work. Chewing betel nut and betel in Malind culture is known as a mat. Betel nut must be provided in a traditional community event. Chewing betel betel is believed to strengthen teeth. The concept of numbers can be seen from its composition.

Figure 3. Chewing pinang sirih as the Culture of the Papua Tribe

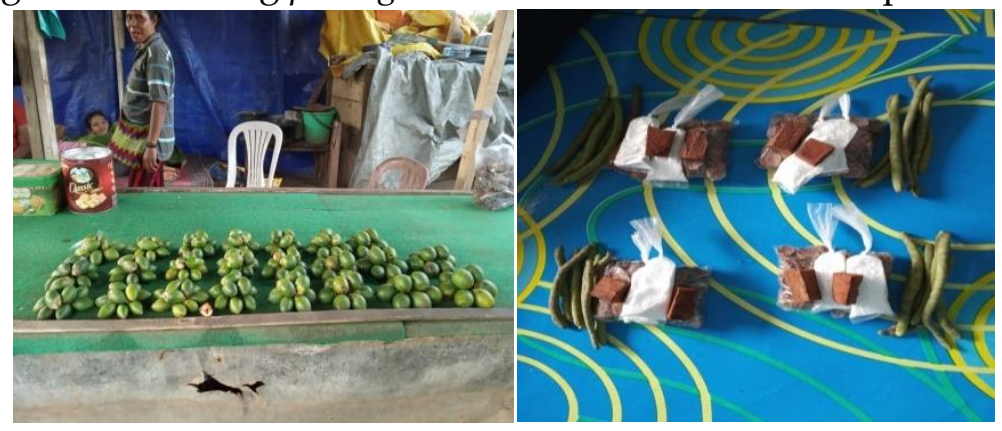


I1 : For eating areca nut, take three slices of dried areca nut, add one piece of betel and gambier to cool. Chalk and betel make red. Biting betel use a little white chalk. Do not heat the tongue much later, burning mouth.

Stone-burning (bakar batu) is a tradition that is still sustainable today. Stoneburning is a cooking event together in a village, usually for a thanksgiving event, (friendship between family or relatives), transfer of land rights and customary parties. The stones used for cooking are really hot burning stones and on top of which are stacked foods that will be cooked such as tubers, sago or other agricultural products and meat (Herningsih, 2018).

I1 : Malind tribe cooks by burning because the food is all burnt. So the Malind cooking utensils are in the form of stones which are burnt to heat and covered with banana sheath and on top of the leaves are sago mixed with coconut and if there is meat the meat continues to be covered again with the banana sheath so that the hot steam from the stone cannot come out. Now there are certain moments that we just cook using stone-burning, such as thanksgiving, death, transfer of land rights and customary parties.

The concept of numbers can be seen from the number of hot stones used. The more hot stones, the higher the heat temperature and the more dishes will be cooked, the more hot stone needs are used.

Noken is a multifunctional bag commonly used by farming mothers to lift heavy agricultural products, firewood, groceries and even can be used to hold babies. How to use it by linking the head of the noken sash or the front of their head and draping it behind the back. Noken is a symbol of hard work, fertility, peace and a good life. In the past, noken was symbolized as independence and maturity of women. If you cannot make noken then it is considered immature and not ready to get married (Elas, 2018). Geometric concepts such as pentagons, rectangles and triangles are very dominant in woven noken. Noken is now widely used by school children and students to store books or other learning materials. In fact many are sold to newcomers as a typical parcel (ole-ole) of Papua.

We can still find traditional houses of the Malind people in several villages. The shape of the traditional house illustrates the concept of geometry. The traditional house of the Malind tribe is called gamaha while the house for family residence is called oram Aaha. There is also a bina hol house which means a place of advice, education, a place of guidance for young children. Malind tribal homes are made of hard or durable wooden bus or getana.

$\mathrm{P} \quad$ : What are the Malind houses made of?

I1 : made of getana wood or bus merah. Skin of bus merah is peeled to make a honai roof with a rope made of fine scraped rattan

Unlike the case with the house on the coast. Their house is called befak shaped hut whose walls and roof are made of palm leaves or sago leaves. Their house is triangular in shape with the front pole of the house higher than the back pole. The Malind tribe also has a house for a single person called a gotad and a house for people to give birth 
called orramaha. The Malind tradition of a mother giving birth cannot live in the same house as her husband and children. This is a taboo that must be avoided.

I1 : The characteristics of malind people sleep in the sand so the house does not look like a house but like a befak (hut), the walls are made of palm leaves or sago leaves, the roof uses sago leaves or bus skin. If for a birthing house in the culture of the Malind tribe, a mother who gives birth must not be in the same house with her husband and children it is a taboo. There is already housing assistance but they prefer to settle in the befak house

The latest information obtained is a traditional game for the Malind children. Arrows are played in teams by children of five to six people. How to play the game using a coconut frond that cut about $50 \mathrm{~cm}$, the ends tied with a rope and one of the players carried off the midrib. Another player called the attacker chases the midrib and shoots it until it hits the midrib. The attacker is the first to hit the midrib, so he is the winner. The game can be started again after all the attackers on the midrib.

$\mathrm{P} \quad$ : Are there traditional Malind games for children?

I1 : there is a game of arrows using coconut fronds. The palm fronds are tied together using a rope and how to play five to six people, but only one person who carries the stem. He carried off the pelepa and the attacker had to use a crossbow after which the bow held had to be shot at the pelepa, when the pelepa was hit the attacker won and the pelapa holder he had at that time, then proceeded with a new game again.

The concept of the distance between the archer and the midrib carrier will affect the chances of the coconut midrib being removed. It takes strength to run fast to chase the midrib. The closer the distance between the archer and the midrib, the greater the chance of the archer hitting his target. The attitude that can be developed in this game is concentration and responsibility for what has been done. Of course, with the spirit of sportsmanship in playing will strengthen the sense of friendship and tolerance between players.

The main findings of this study are the result of exploration ethnomathematics on Malind tribal culture produced some mathematical material that can be used for learning mathematics in elementary school. Among them the concept of numbers and operations, measurements of length and distance, angles, plane, and solid (geometry). Mathematical material is found in the culture of making tools for farming, hunting, fishing, musical instruments, noken, ornaments and paintings, traditional ceremonies, life behaviors, and traditional games. In that culture also contains character values that can be used for character development in elementary schools such as the attitude of responsibility, like to work hard, practice religious values, develop creativity, friendship, responsibility, a spirit of mutual cooperation and kinship, and tolerance. Ethnomathematics findings can be integrated into mathematics learning in elementary schools, as one way to provide reinforcement of character values in students. The teacher can study the activities or products of local culture and then relate them to competency standards and mathematics material.

The results of this study are relevant to previous research conducted by Richardo (2016) in his research explaining ethnomathematics support in character strengthening. The existence of affective competence in ethnomathematics is able to create an attitude of tolerance, patriotism that is rooted in the noble values of the Indonesian nation (Kerimbayev \& Akramova, 2015). Ethnomathematics is not just a collection of definitions, theorems, or axioms, but in ethnomathematics, there are 
elements of local culture that can influence the actions and attitudes (mindset) of the local community (Wahyuni et al., 2013). The teacher can emphasize the importance of these cultural values so that students are expected to understand mathematics material well and understand cultural values to strengthen their character. The emphasis on cultural values is very important for the teacher to do. The emphasis in question is to invite students to apply these cultural values in learning and the school environment so that they become a habit (habituation) in their daily lives.

Ethnomathematics can bridge abstract mathematics, especially in elementary schools, into concrete in accordance with experiences in daily life. Most students do not understand mathematical material well because they are not able to link the material learned with its implementation in everyday life (Loli et al., 2018). Students will more easily understand mathematical material if it is associated with their own culture. The teacher can study the positive values contained in the culture and relate it to the character of the nation. Ethnomathematics that links mathematics material with culture provides a more meaningful learning experience, not only can help students understand the material but also can assess the positive values contained therein.

\section{CONCLUSIONS}

First, ethnomathematics in the Malind culture is found in daily life activities such as making farming tools, hunting, fishing, musical instruments, noken, ornaments and paintings, traditional ceremonies, life behavior, and traditional games. Secondly, the attitude of responsibility, like to work hard, practice religious values, develop creativity, friendship, responsibility, the spirit of mutual cooperation and kinship and tolerance is an integrated national character in the cultural values of the Malind community. Third, ethnomathematics can be integrated into learning mathematics in elementary schools. It is hoped that students can understand mathematical material well and appreciate the cultures of the local community (Malind tribe as indigenous of Merauke) and take the values contained therein to strengthen their character.

\section{ACKNOWLEDGEMENTS}

Thanks for the Rector Universitas Musamus for guidance who has given motivation to author to immediately complete this research. All parties involved in this study. This research was funded by DIPA No. SP DIPA.042.01.2.401023/2019 revision 04 of 23 July 2019 In accordance with the Internal Research Contract of Universitas Musamus, No. 261.13/UN52.8/LT/2019, 9 September 2019.

\section{AUTHOR CONTRIBUTION STATEMENTS}

Fredy (F) was the main author in this article. Yonarlianto Tembang (YT), Gregorius Sebo Bito (GSB), and Octarina Hidayatus Sholikhah (OHS) helps to evaluate this research. The authors approve this text as the result of research to explore ethnomatematics in the Malind culture. It is hoped that students can understand mathematical material well and appreciate the cultures Malind tribe as an indigenous tribe of Merauke and take the values contained therein for their character building.

\section{REFERENCES}

Adam, A., Susanto, I., \& Zainuddin, Z. (2019). Social control of misbehavior among muslim youth in bima district, indonesia. Jicsa (Journal of Islamic Civilization in Southeast Asia), 7(2), 216-242. https:/ / doi.org/10.24252/jicsa.v7i2.6790

Afriyanty, M., \& Izzati, N. (2019). Eksplorasi Etnomatematika pada Corak Alat Musik 
Kesenian Marawis sebagai Sumber Belajar Matematika. Jurnal Gantang, 4(1), 3948. https://doi.org/10.31629/jg.v4i1.1027

Agustin, R. D., Ambarawati, M., \& Kartika, E. D. (2018). Development of mathematical learning instruments based on ethnomathematics in character education learning. International Journal on Teaching and Learning Mathematics, 1(1), 24-30. https:// doi.org/10.18860/ijtlm.v1i1.5353

Amri. (2017). Tradisi Peminangan dan Walimat Al Urs Masyarakat Muslim Suku Marind Kabupaten Merauke Perspektif Akulturasi Budaya. UIN Maulana Malik Ibrahim Malang. Google Schoolar

Ampuni, S., Kautsari, N., Maharani, M., Kuswardani, S., \& Buwono, S. B. S. (2019). Academic Dishonesty in Indonesian College Students: an Investigation from a Moral Psychology Perspective. Journal of Academic Ethics. https:// doi.org/10.1007/s10805-019-09352-2

Creswell, J. W. (2014). Penelitian Kualitatif dan Desain Riset, Memilih diantara Lima Pendekatan. Yogyakarta: Pustaka Pelajar. Google Sholar.

Dinas Kebudayaan dan Pariwisata. (2015). Kumpulan Cerita Rakyat Daerah Malind. Merauke: Dinas Kebudayaan dan Pariwisata Kabupaten Merauke. Google Schoolar

E. Elas. (2018). Keunikan Acara Adat Bakar Batu dan Noken sebagai Daya Tarik Wisata Budaya Masyarakat di Papua. Domestic Case Study. Sekolah Tinggi Pariwasata Ambarrukmo Yogyakarta. Google Schoolar

Edmonson, S., Tatman, R., \& Slate, J. R. (2009). Character Education: An Historical Overview. International Journal of Educational Leadership Preparation, 4(1), n1. Google Scholar

Fredy, F., Halimah, L., \& Hidayah, Y. (2020). Malind-Papua Ethnomathematics: Kandara Musical Instrument as Learning Media for Geometry Concepts in Elementary School. Jurnal Iqra' : Kajian Ilmu Pendidikan, 5(1), 43-57. https:// doi.org/10.25217/JI.V5I1.872

Herawaty, D., Widada, W., Nugroho, K. U. Z., \& Anggoro, A. F. D. (2019). The Improvement of the Understanding of Mathematical Concepts through the Implementation of Realistic Mathematics Learning and Ethnomathematics. Atlantis Press. https:// doi.org/10.2991/icetep-18.2019.6

Herningsih, H. (2018). Kebijakan Pemerintah Papua dalam Pelestarian Tradisi Bakar Batu. Journal of Islamic Studies and Humanities, 3(2), 209. https:// doi.org/10.18326/mlt.v3i2.209-226

Yustinaningrum, B., Nurliana, \& Rahmadhani, E. (2018). The ethnomathematics: exploration of Gayo tribe local wisdom related to mathematics education. 1088, 012061. https:// doi.org/10.1088/1742-6596/1088/1/012061

Kerimbayev, N., \& Akramova, A. (2015). Kazakh History and Philosophy: the Ethnomathematical Component of the Content of Primary School Education in the Republic of Kazakhstan. ArXiv:1503.05418 [Math]. http://arxiv.org/abs/1503.05418

Kurniawan, W., \& Hidayati, T. (2020). Ethnomathematics in Borobudur Temple and Its Relevance in Mathematics Education: A Literature Study. Jurnal Pendidikan Progresif, 10(1), 91-104. https:// doi.org/10.23960/jpp.v10.i1.202011

Loli, K. J., Damayanti, N. W., \& Yuniarto, E. (2018). Pengembangan Lks Berdasarkan Masalah Kontekstual Pada Materi Operasi Hitung Bentuk Aljabar. Edu Sains: $\begin{array}{lllll}\text { Jurnal Pendidikan Sains } \mathcal{E} \text { Matematika, } & \text { 6(1), } 30 .\end{array}$ https:// doi.org/10.23971/eds.v6i1.897

McAlpin, M. (2016). Female Sexuality and Cultural Degradation in Enlightenment 
France: Medicine and Literature. Routledge.Google Scholar

Mutijah. (2018). Model Integrasi Matematika dengan Nilai- Nilai Islam dan Kearifan Lokal Budaya dalam Pembelajaran Matematika. Jurnal Pendidikan Matematika, 1(2), 52-75. http:/ / dx.doi.org/10.21043/jpm.v1i2.4878

Muthohar, S. (2016). Antisipasi Degradasi Moral di Era Global. Nadwa, 7(2), 321-334. https:// doi.org/10.21580/nw.2013.7.2.565

Ndiken, I. yanggel. (2013). Etnolinguistik: Kamus Bahasa Malind Jilid I.

O'Dwyer, L. M., \& Bernauer, J. A. (2013). Quantitative Research for the Qualitative Researcher. SAGE Publications. Google Schoolar.

Nugroho, G. N. (2018). Penanaman Pendidikan Karakter melalui Pembelajaran Etnomatematika. Prosiding Seminar Nasional Pendidikan FKIP Universitas Muhammadiyah Cirebon 2018, 193-201. Google Schoolar

Richardo, R. (2016). Peran Ethnomatematika dalam Penerapan Pembelajaran Matematika. Jurnal Literasi, $\quad 7(2), \quad 118-125$. http:/ / dx.doi.org/10.21927/literasi.2016.7(2).118-125

Risdiyanti, I., \& Prahmana, R. C. I. (2017). Ethnomathematics: Exploration in Javanese culture. Journal of Physics: Conference Series, 943, 012032. https:// doi.org/10.1088/1742-6596/943/1/012032

Santos, M. (2019). Units of Measurement in Social Practices: An Ethnomathematic Study. American International Journal of Contemporary Research, 9(2), 32-39. https:// doi.org/10.30845/aijcr.v9n2p4

Supriyadi, \& Nurvitasari, E. (2019). Inventarisasi Sains Asli Suku Malind: Upaya dalam Pengembangan Kurikulum IPA Kontekstual Papua Berbasis Etnosains. EduSains: Jurnal Pendidikan Sains Dan Matematika, 7(1), 10-21. https:// doi.org/10.23971/eds.v7i1.1081

Wahyuni, A., Tias, A. A. W., \& Sani, B. (2013). Peran Etnomatematika dalam Membangun Karakter Bangsa. Seminar Nasional Matematika Dan Pendidikan Matematika Dengan Tema " Penguatan Peran Matematika Dan Pendidikan Matematika Untuk Indonesia Yang Lebih Baik", 978-979. Google Schoolar 